\title{
ASSESSMENT OF THE RISKS OF RATS (RATTUS NORVEGICUS) AND OPOSSUMS (DIDELPHIS ALBIVENTRIS) IN DIFFERENT POULTRY-REARING AREAS IN ARGENTINA
}

\author{
Isabel E. Gómez Villafañe ${ }^{1,2 *}$; Fernando Miñarro ${ }^{1}$; Mabel Ribicich ${ }^{3}$; Carlos A. Rossetti ${ }^{4}$; Daniel Rossotti; \\ María Busch ${ }^{1,2}$ \\ ${ }^{1}$ Universidad de Buenos Aires, Facultad de Ciencias Exactas y Naturales, Departamento de Ecología, Genética y Evolución; \\ ${ }^{2}$ Consejo Nacional de Investigaciones Científicas y Tecnológicas; ${ }^{3}$ Universidad de Buenos Aires, Facultad de Ciencias \\ Veterinarias, Area de Parasitología y Enfermedades Parasitarias; ${ }^{4}$ Instituto de Patobiología, INTA Castelar; ${ }^{5}$ Empresa de Control \\ Bromatológico Tecnofood
}

Submitted: June 12, 2003; Returned to authors for corrections: February 12, 2004; Approved: October 02 , 2004

\begin{abstract}
We have studied the prevalence of Trichinella spiralis, Leptospira spp. and Salmonella spp. in rats and opossums that inhabit poultry farms of Exaltación de la Cruz, Buenos Aires, Argentina, to determine the potential sanitary risk for humans that are in contact with these animals. The study was carried out on 48 poultry farms between spring 1999 and winter 2001. The study of opossums began in winter 2000. During the study period we captured 152 Rattus norvegicus, 3 Rattus rattus, 16 Didelphis albiventris and 1 Lutreolina crassicaudata. We have registered the presence of rats and opossums in $70 \%$ and $27 \%$ of the studied farms, respectively. The percentage of farms with rats was independent of the presence or absence of pigs. We did not detect the presence of Leptospira spp. and Trichinella spiralis in any individual. We detected the presence of Salmonella Enteritidis in one Rattus norvegicus and one Didelphis albiventris. According to our results, the rats and opossums of poultry farms may not report a risk factor in the transmission of Trichinella and Leptospira under the present conditions; but the detection of Salmonella Enteritidis in rats as well as in opossums suggests the idea of applying prophylactics measurements on poultry farms.
\end{abstract}

Key words: zoonosis, Salmonella, poultry farms, rats, opossum

\section{INTRODUCTION}

Rodents are potential zoonoses transmitters, such us Argentine Hemorrhagic Fever, Hantavirus (pulmonary and renal syndrome), leptospirosis, salmonellosis, trichinosis and lymphocitic coriomeningitis $(1,24,27,32)$. Commensal rodents, such as rats, are in intimate contact with human beings and domestic animals, so they can disseminate disease to them throughout feces, urine and hair remnants.

Opossums are also potential zoonoses transmitters such as "Doença de Chagas" (29), leptospirosis and salmonellosis and they are an important link between the wild and domestic habitat.
The etiologic agent of trichinosis is the nematode Trichinella spiralis. The main hosts are pigs, rats and mice in domestic habitats. The sylvan reservoirs are omnivorous and carnivorous animals with cannibalistic and scavenging behavior. The domestic cycle is usually confined to small farms where the pigs are bred without microbiological barriers or veterinary controls (26). The role of rats in the maintenance and transmission of T. spiralis is a matter of controversy. According to Leiby et al. (19), Rattus norvegicus is the most important animal in the transmission and maintenance chain of trichinosis, whereas Madsen (21) said that rodents are accidental hosts in areas where the parasites have been previously present in pigs.

*Corresponding author. Mailing address: Laboratorio de Ecología de Poblaciones (63 ó 104). Pabellón II. 4 piso. Facultad de Ciencias Exactas y Naturales. Departamento de Ecología, Genética y Evolución. Ciudad Universitaria (C1428EHA). Universidad de Buenos Aires, Buenos Aires. Argentina. Tel.: (+5411) 4576-3300 int 219; Fax: (+5411) 4576-3384. E-mail: isabelgv@ bg.fcen.uba.ar 
There are no reports of rats infected with Trichinella in areas where the parasite has not been detected in wildlife or in domestic pigs. In Europe, Trichinella was detected in $73 \%$ of rats coming from food storage areas and in $6 \%$ of rats coming from pigpen. Rats coming from granaries, sheds and areas far from animal breeder places and slaughterhouses did not carry parasites (13). Human beings are accidental hosts that acquire trichinosis through the consumption of undercooked infected pork meat. During the last century (1900-1998), human cases of trichinosis in Buenos Aires Province reached 2731, resulting in 303.5 mean cases per year (7). Few studies about trichinosis in wild animals were made in Argentina, but the agent was detected in rodents, foxes, armadillos, wild boars and large hairy armadillos (Chaetophractus villosus) $(1,15,33)$.

Leptospirosis is a worldwide disease with approximately $1 \%$ lethality. Rats are the main carriers of leptospires and they are important transmitters of infections to human beings and domestic animals. In poultry farms the rodents attracted to foodstuffs may infect chickens, especially in bad hygiene conditions, posing a danger to poultry processors (8). Furthermore, the critical number of rats for maintenance of leptospirosis in an area is estimated to be about two individuals per hectare, because in this way at least two rats would overlap their home range about half the time of its active life (14). According to studies carried out in Peru, Brazil and Argentina, Didelphis is the second main reservoir of leptospires $(6,20,28)$. Leptospires were isolated from other animals, such as pampa's cavys, otters, hares and sigmodontine rodents $(3,30)$. Human beings may become infected when they have contact with moist soil that contains infected urine. To create a leptospires focus, the presence of infected animals as well as particular habitat conditions (wet conditions, neutral or neutral-alkaline $\mathrm{pH}$, temperate temperature) are needed. The prevalence in rodents that inhabit Buenos Aires downtown and its suburbs varied between $12.5 \%$ and $43 \%$ depending on the zone, environmental conditions and season $(2,30,31)$.

Salmonellosis is an important disease both for human health and for the economic losses that causes to the poultry activity $(16,17)$. The global increase of human infections due to serovar Enteritidis observed between 1980-1990 was almost entirely attributable to the presence of this organism in the poultry production industry worldwide (4). According to the Hungarian enteric surveillance data, human salmonellosis is mostly due to $S$. Enteritidis infection, caused by ingestion of food of poultry origin (meat and egg products) (23). The etiologic agent (Salmonella spp.) can be transmitted by chickens through vertical way, which can result in the contamination of a flock, or in the case of embryonic mortality, resulting in contaminated eggs (16). Therefore, different countries state that infected flocks of breeding birds should be destroyed, and that prophylaxis measurements should be implemented (16). The infection rate has been estimated to be between $1-3 \%$ in domestic animals and around 3.4\% in wild animals (opossums mainly) (1). Generally, rodents are infected with particular serotypes of the resident area.

The broiler industry is an activity that has increased worldwide; so, the goal of this study was to detect the prevalence of Trichinella spiralis, Leptospira spp and Salmonella spp in rats and opossums that inhabit poultry farms in the study area aiming to asses the potential risk posed by these animals to the human population.

\section{MATERIALS AND METHODS}

\section{Study area}

Fieldwork took place in Exaltación de la Cruz County, Buenos Aires Province, Argentina. The area is a gently sloping plain in the pampean subregion. The climate is temperate, with a mean annual temperature of $16^{\circ} \mathrm{C}$ and a mean annual precipitation of $1000 \mathrm{~mm}$.

The area is intensely cultivated, and most of the remaining native plants are restricted to linear and less disturbed habitats including cropfield edges, fencerows and roadsides, typically known as 'borders' $(5,22)$. Other activities include extensive cattle farming and intensive poultry farming, mainly for the broiler industry, which has increased in the area in the last 14-19 years (12).

In poultry farms, seven-day-old chickens are provided to the farmers by large integrated breeding companies. When they are in their sheds, chickens are kept on litter floors, receive a constant supply of food and water and are maintained at a comfortable temperature. The chickens are reared for about 60 days and then sold as meat to the company. Within the next 20 days the sheds are prepared for new chickens. Usually, this is the period when sheds are treated with chemical for rodent control. However, farms may remain untreated for some periods because the company does not provide the poison, or the farmer decides not to use it.

\section{Rodent and opossum survey}

The study was carried out on 48 poultry farms (six for each season) located in Exaltación de la Cruz County, NW Buenos Aires province, Argentina, between spring 1999 and winter 2001. The opossums sampling began in winter 2000.

Cage live traps $(15 \times 16 \times 31 \mathrm{~cm}$.) were placed around the chicken sheds (maximum of three sheds per farm) and other buildings every 20 meters. Traps were baited with meat and carrots and checked each morning during three consecutive days.

The relationship between presence of rats on farms and the presence of pigs for the farmers consumption was determined by means of Chi-square Test (36).

Captured rodents and opossums were identified to species level. Breeding condition, trap location and date of capture were recorded. Animals were euthanized and the age of the rodent was determined by the dry weight of eye lens (18). 


\section{The prevalence was calculated as follows}

Number of hosts infected with one or more individuals of a particular parasite

number of hosts examined for this particular parasite

\section{Leptospira spp. detection}

Two methods were used: serology and Warthin-Starry. Due to problems of contamination of samples when working in field conditions, the second method was selected for analysing the samples. Although this method may underdiagnose the presence of Leptospira, Fresh et al. (10) and Zamora et al. (35) detected $83.3 \%$ of the cases and results were comparable to the ones obtained using serological methods $(10,34)$.

At necropsy, the kidneys of each animal were removed and transversal sectioned in half. The kidneys were then fixed in $10 \%$ buffered formalin. Sections of each kidney were silver impregnated according to the Warthin-Starry methods (9) and observed at light microscopy.

\section{Trichinella spiralis detection}

At necropsy, the tongue, intercostal muscles and diaphragm were removed and preserved at $0-5^{\circ} \mathrm{C}$. Artificial digestion methods were used for detection of $\mathrm{L}_{1}$ Trichinella spiralis (11).

\section{Salmonella sp. detection}

At necropsy, a terminal intestine portion was removed and sowed in a plate containing cromogenic Chromagar Salmonella. The potential positive samples were confirmed by serological tests, using somatic $(\mathrm{O})$ and flagellar $(\mathrm{H})$ polyvalent sera $(34)$.

\section{RESULTS}

During the study period 160 rats (152 Rattus norvegicus, 3 Rattus rattus and 5 unknown) and 17 opossums (16 Didelphis albiventris and 1 Lutreolina crassicaudata) were captured by means of a total trapping effort of 4382 trap-nights.

Fourty-nine percent of farms had pigs for the farmer consumption. The presence of rats and opossums was registered in $70 \%$ and $27 \%$ of the studied farms, respectively. The presence of rats on farms resulted independent of the presence or absence of pigs $\left(X^{2}=0.17 ; \mathrm{p}=0.68\right)$.

Neither Leptospira spp. nor Trichinella spiralis was detected in any of the individuals analysed (105 rats and 17 opossums; 129 rats and 17 opossum, respectively).

The presence of Salmonella Enteritidis was detected in one of the 123 Rattus norvegicus analysed (prevalence $=0.81 \%$ ) and in one of the 16 Didelphis albiventris analysed (prevalence= $6 \%$ ). The infected rat was a reproductively active female, older than 20 months weighing 310 grams, which had recently bred and captured in autumn 2001. The infected opossum was a juvenile female weighing 110 grams, captured in summer 2001.

\section{DISCUSSION}

In the studied poultry farms, the most common rat and opossum species were Rattus norvegicus and Didelphis albiventris respectively.

The absence of Trichinella spiralis in rats supports the hypothesis of Madsen (21) which says that they are accidental hosts which may be infected by the consumption of infected pigs carcasses. The absence of infected rats in the study area may be related to the periodical control of pigs conducted by the Bromatology Direction of Exaltación de la Cruz, and to the high availability of food sources for rats (chicken food) which decreases the probability of eating carcasses $(1,26)$. In agreement with this hypothesis, Caminoa (7) found infected rats in sites where pigs were also infected.

The non-detection of leptospires in rats may have been caused by the absence of this parasite in the studied habitat, but may have been also the result of the use of antibiotics to control chickens, and rodenticides to control the rats $(3,7,33)$.

Generally, rodents are infected with particular Salmonella serotypes, so, the detection of Salmonella Enteritidis in rats suggests that the chickens were infected with the same serotype, which implies a serious risk to human health. This serotype arose as a problem for the broiler industry in Spain in 1983 and it was treated as a serious problem in 1985 and 1986 because there is a positive relationship between humans isolation of $S$. Enteritidis and the consumption of chickens, eggs and their products (25).

According to these results, the rats and opossums of poultry farms in the study area are not a risk factor in the transmission of Trichinella and Leptospira. However, the presence of $S$. Enteritidis indicates the need for application of prophylactic measures in poultry farms which must include the creation of sanitary barriers at building entrances (13), heat treatment of feed and control of wild animals entrance.

\section{ACKNOWLEDGEMENTS}

We want to thank all the farmers who kindly let us work on their farms and the following sources of financial support: University of Buenos Aires and National Council of Scientific and Technologic Research (CONICET) grants (UBACYT TX 58 and PIP 548/98).

\section{RESUMO}

Avaliação dos riscos sanitários de ratos

(Rattus norvegicus) e gambás (Didelphis albiventris) em diferentes granjas avícolas na Argentina

A prevalência de Trichinella spiralis, Leptospira spp. e Salmonella spp. foi estudada em ratos e gambás que habitam granjas avícolas da região de Exaltación de la Cruz, Buenos 
Aires, Argentina, com o objetivo de determinar o potencial risco sanitário para pessoas que ficam em contato com esses animais. O estudo foi realizado entre a primavera de 1999 e o inverno de 2001 em 48 granjas avícolas. O estudo em gambás iniciou-se no inverno de 2000. Foram capturados 152 Rattus norvegicus, 3 Rattus rattus, 16 Didelphis albiventris e 1 Lutreolina crassicaudata. Registrou-se a presença de ratos e de gambás em $70 \%$ e $27 \%$ das granjas estudadas, respectivamente. A percentagem de granjas com ratos foi independente da presença ou da ausência de suínos. Não foi detectada a presença de Leptospira spp. e de Trichinella spiralis em nenhum animal avaliado. Foi detectada, porém, a presença de Salmonella Enteritidis em um Rattus norvegicus e em um Didelphis albiventris. Nas condições em que esse estudo foi realizado, os nossos resultados indicam que ratos e gambás que habitam granjas avícolas não constituem um fator de risco na transmissão de Trichinella e de Leptospira. A detecção de Salmonella Enteritidis tanto em ratos quanto em gambás, porém, sugere a necessidade de aplicar medidas profiláticas em granjas avícolas para maior controle desse agente.

Palavras-chave: zoonose, Salmonella, granjas avícolas, ratos, gambás

\section{REFERENCES}

1. Acha, P.N.; Szyfres, B. Zoonosis y enfermedades transmisibles comunes al hombre y a los animales. Organización Panamericana de la Salud, 1992, 953p.

2. Agostini, A.; Arango, J.F.; Cittadino, E.A.; de Mazzonelli, G.D. Leptospirosis humana: caracterización epidemiológica de un área de riesgo. Revista del Instituto de Higiene y Medicina Social, 3:14-21, 1999.

3. Amaddeo, D.; Ieradi, L.A.; Autorino, G.L.; Perrella, D. Leptospirosis in wild rodents living in urban areas (Rome-Italy). Proccedings of the I European Congress of Mammalogy, 105-114, 1996.

4. Brown, D.J.; Browning, L.M.; Coia, J.E. Investigation of human infections with Salmonella enterica serovar Java in scotland and possible association with imported poultry. Eurosurveillance, 2:3540, 2003.

5. Busch, M.; Kravetz, F.O. Competitive interactions among rodents (Akodon azarae, Calomys laucha, C. musculinus and Oligoryzomys flavescens) in a two-habitat system I. Spatial and numerical relationship. Mammalia, 56:45-56, 1992.

6. Cacchione, R.A.; Bulgini, M.J.D.; Cascelli, E.S.; Martinez, E.S. Leptospirosis en animales silvestres. Estado actual de sus investigaciones, aislamientos y clasificación de cepas argentinas. Rev. Fac. C. Vet., 20:37-54, 1967.

7. Caminoa, C. Roedores como transmisores de leptospirosis y triquinosis. Agrevo. Super Asecho, without year.

8. Everard, C.O.R.; Fraser-Chanpong, G.M.; James, A.C.; Butcher, L.V. Serological studies on leptospirosis in livestock and chickens from Grenada and Trinidad. Trans. R. Soc. Trop. Med. Hyg., 79:859-864, 1985.

9. Faine, S. Silver staining of spirochaetes in single tissue sections. $J$. Clin. Pathol., 18:381-382, 1965.

10. Fresh, J.W.; Tsai, C.C.; Lai, C.H.; Chang, C.T. Leptospirosis in man and rodents on Taiwan. Am. J. Trop. Med. Hyg., 17:760-768, 1968
11. Gamble, H.R.; Bessonov, A.S.; Cuperlovic, K.; Gajadhar, A.A.; Van Knapen, F.; Noeckler, K.; Schenone, H.; Zhu, X. International Commission on Trichinellosis: Recommendations on methods for the control of Trichinella in domestic and wild animals intended for human consumption. Veterinary Parasitology, 93:393-408, 2000.

12. Gómez Villafañe, I.E.; Bilenca, D.N.; Cavia, R.; Miño, M.H.; Cittadino, E.A.; Busch, M. Environmental factors associated with rodent infestations in Argentine poultry farms. Br. Poult. Sci., 42:300-307, 2001.

13. Gonzalez, H.D.; Floriani, C. Capítulo XXII In: Tratado de las enfermedades infecciosas. $2^{\text {a }}$. edición. Editorial Bibliográfica Argentina, 1950, 232-239.

14. Gordon Smith, C.E.; Turner, L.H.; Harrison, J.L.; Broom, J.C. Animal leptospirosis in Malaya. Bull. Wld. Hlth Org., 24:23-34, 1961.

15. Huici, N.; Tesón, M.; Macazaga, A.; Loverde, V. Triquinelosis en algunos animales autóctonos argentinos. Veterinaria Argentina, volumen XVI:358-360, 1999.

16. Hoop, R.K. The Swiss control programme for Salmonella Enteritidis in laying hens: experiences and problems. Rev. Sci. Tech. Off. Int. Epiz., 16:885-890, 1997

17. Humbert, F.; Salvat, G. Risques de transmission des Salmonelles en aviculture: détection et prévention en Europe. Rev. Sci. Tech. Off. Int. Epiz., 16:83-90, 1997.

18. Kataranovski, D.; Dataranovski, M.; Savic, I.R.; Cakic, P.; Soldatovic, B.; Matic, R. Morphometric and biochemical parameters as age indicators in the Norway Rat (Rattus norvegicus Berk, 1769). Acta Vet., 44:371-378, 1994.

19. Leiby, D.A.; Duffy, C.H.; Murrell, K.D.; Schad, G.A. Trichinella spiralis in an agricultural ecosystem: transmission in the rat population. J. Parasitol., 76:360-364, 1990.

20. Liceras de Hidalgo, J. Leptospirosis en Tingo María, Departamento de Huanuco, Perú. II. Estudio en animales silvestres. Bol. Sanit. Panam., 91:47-54, 1981.

21. Madsen, H. The principles of the epidemiology of trichinelliasis with a new view on the life cycle. In: Kim, C.W. (ed.) Trichinellosis. Intext, New York, 1974, p.615-638.

22. Mills, J.N.; Ellis, B.; McKee, K.; Maiztegui, J.; Childs, J.E. Habitat associations and relative densities of rodent populations in cultivated areas of Central Argentina. J. Mammal., 73:470-479, 1991.

23. Nagy, B.; Kovacs, S.; Kostyak, A.; Bitay, Z. Significance of salmonellosis in food safety and opportunities to reduce losses in Hungary. Magyar-Allatorvosok-Lapja, 119:672-685, 1997.

24. Padula, P.J.; Colavecchia, S.B.; Martinez, V.P.; Gonzalez Della Valle, M.O.; Edelstein, A.; Miguel, S.D.; Russi, J.; Riquelme, J.M.; Colucci, N.; Almiron, M.; Rabinovich, R.D. Genetic diversity, distribution, and serological features of hantavirus infection in five countries in South America. J. Clin. Microbiol., 38:3029-3035, 2000.

25. Porta, R. Problemática actual de la Salmonella Enteritidis. In: Mundo Ganadero. № 12. Ed. Eumedia, S.A. Madrid, 1999.

26. Pozio, E. Factors affecting the flow among domestic, synanthropic and sylvatic cycles of Trichinella. Vet. Parasitol., 93:241-262, 2000.

27. Sabattini, M.; Maiztegui, J.I. Fiebre Hemorrágica Argentina (FHA). Medicina, 34:313-320, 1970.

28. Santa Rosa, C.A.; Sulzer, C.R.; Giorgi, W.; da Silva, A.S.; Yanaguita, R.M.; Lobao, A.O. Leptospirosis en Wildlife in Brazil: Isolation of a New serotipe in the pyrogenes group. Am. J. Vet. Res., 36:1363$1365,1975$.

29. Schweigmann, N.J.; Pietrokovsky, S.; Bottazzi, V.; Conti, O.; Bujas, M.A.; Wisnivesky-Colli, C. Estudio de la prevalencia de la infección por Trypanosoma cruzi en zarigüeyas (Didelphis albiventris) en Santiago del Estero, Argentina. Revista Panamericana de la Salud, 6:371-377, 1999.

30. Seijo, A.; Deodato, B.; Cernigoi, C.; Curcio, D. Source of infection for leptospirosis in Argentina. Abstract Book of the $9^{\text {th }}$ International Congress on Infectious Diseases, Buenos Aires, Argentina, 2000, p.235. 
31. Seijo, A. Leptospirosis, un problema de salud pública. Boletín de Temas de Salud. Suplemento del diario del Mundo Hospitalario, 67, 2001.

32. Taylor, K.D.; Turner, L.H.; Everard, J.D. Leptospires in Rattus spp on Barbados. J. Trop. Med. Hyg., 94:102-103, 1991.

33. Tesón, M.; Huici, N.; Regis, A.; Movak, F. Triquinelosis en jabalíes en el departamento Lacar, Neuquén. Veterinaria Argentina, 14:187190, 1997.
34. Andrews, W.H.; Hammack, T.S. Bacteriological Analytical Manual Online. http://vm.cfsam.fda.gov/ ebam/bam-5.html, 2001.

35. Zamora, J.; Riedemann, S.; Cabezas, X.; Vega, S. Comparación de cuatro técnicas microscópicas para el diagnóstico de Leptospirosis en roedores silvestres en el área rural de Valdivia, Chile. Rev. LatAmer. Microbiol., 37:267-272, 1995.

36. Zar, J. Biostatistical Annalysis. Third edition. Prentice-Hall, inc. United Stated of America, 1996, 662p. 